$\begin{array}{lllllllllllll}C & R & O & N & I & C & A\end{array}$

\title{
El Milagroso de La Villa: El Abogado de los Pobres
}

\author{
Por: Edgar Rey Sinning
}

\begin{abstract}
“Cristo de Los Milagros, -dulcísimo Jesús Guarda siempre a esta Villa(nuestro Rey eres Tú)" Estrofa del Himno al Señor de Los Milagros
\end{abstract}

Por fin hemos llegado. Son las tres de la mañana de un sábado caluroso del mes de marzo. Estamos en la Villa de San Benito Abad. Hemos cumplido el deseo de ir a conocer de cerca lo que sucede durante dos días en este municipio sucreño, localizado a las orillas de la ciénaga del mismo nombre. Ya los tenderetes de los vendedores trashumantes están por todas partes. También han llegado campesinos (agropescadores), unos por carretera, otros por agua, convertidos para estas fechas en vendedores de abanicos de mano, mochilas, pellones, hamacas, sombreros. Además, de pescado, loros, pericos y hasta bultos de leña. Por todas partes se ofrece productos tradicionales o algunos inventos nuevos.

A medida que corre el día, crece el número de feligreses. Promeseros o penitentes que llegan a pagar mandas de todas partes de la Costa Caribe y del resto del país. El pueblo se ha transformado, sus habitantes se han triplicado. No hay residencia que no se haya convertido en hotel de paso. Las hamacas decoran con sus múltiples colores los rincones de las casas y los patios. Los recién llegados se acomodan en cualquier lugar y pagan bien por estar dos noches en la Villa. El pueblo se ha convertido en un mercado persa.

${ }^{1}$ Nombre del poblado, en lengua nativa.

${ }^{2}$ Santo que el Papa Pablo VI, en 1964, lo declaró como Patrono Principal de Europa.
La fiesta, en homenaje a la efigie de El Milagroso, originó la Feria de Tacasuán ${ }^{1}$. Conocida -hasta hoy- como la Villa de San Benito Abad, la población fue fundada en 1669 por el gobernador don Benito Figueroa y Barrantes, con el nombre de Villa San Benito Abad de Tacasuán. Todos los pueblos fundados por los conquistadores españoles tienen un protector, un Santo Patrono que los protege, al que los pobladores le rinden culto anualmente. Sin embargo, en la Villa la fiesta cristiana principal no es el 11 de julio, día que la iglesia católica conmemora la fiesta a San Benito Abad ${ }^{2}$, sino el 14 de septiembre, día que la Iglesia católica conmemora la Exaltación de la Santa Cruz. La explicación de esta fiesta dice que "la glorificación de Cristo pasa a través del suplicio de la cruz y la antítesis sufrimiento-glorificación se hace fundamental en la historia de la Redención: 
Cristo, encarnado en su realidad concreta humano-divina, se somete voluntariamente a la humillante condición de esclavo (la cruz, del latín "crux", es decir, tormento, estaba reservada a los esclavos) y el infame suplicio se transforma en gloria imperecedera. Por eso la cruz es el símbolo y el compendio de la religión cristiana" ${ }^{3}$. La razón de la fiesta es conocida desde siempre. El Cristo Milagroso fue traído desde La Coruña (España) en 1678 "para extirpar toda idolatría pagana". Esta imagen forma parte de la trilogía que llegó al país revestida de cierta leyenda popular y que ha sido recogida por varios autores, entre ellos el sociólogo Orlando Fals Borda. La leyenda afirma que los tres Cristos llegaron en sendos cajones primero a Mompox, llevados por tres "caballeros". "Esos señores no pagaban arriendo, ni comían, ni bebían, ni nada, pero daban como golpes de martillo sobre madera. Al cuarto día la señora que les alquilaba la pieza decidió llamarlos para ver si estaban vivos o muertos. Nada. Decidió romper la cerradura y abrió. Vio entonces tres imágenes en los cajones, cada caja llevaba un nombre: Villa de Mompox, Villa de Zaragoza y Villa de Tacasuán. Se formó la bulla de los tres Cristos y así se repartieron. Trajeron el de aquí, que es nuestro Milagroso moreno. Al blanco lo dejaron en Mompox; y al de Zaragoza, cuando llegó, un loco le arrancó una costilla que reemplazaron después con una astilla de maquenque (un árbol nativo) de la que mana sangre de vez en cuando" ${ }^{4}$. El profesor Lácides Paternina Gutiérrez completa la leyenda agregando que los "caballeros" eran trillizos.

Es posible que Luis Striffler no conociera la leyenda o simplemente no le pareció representativa, porque en su libro sobre el río San Jorge afirma que es una efigie elaborada por un "artista indígena" y que es "la efigie de un buen indio". Argumenta que "el tipo indio está estampado en todo su cuerpo. Si el artista trabajó la estatua sin tener a la vista un modelo natural, tenía en la memoria todas las facciones típicas del indio, que presentan muy notables diferencias con las otras dos razas...Se sabe que la prominencia del abdomen es lo que principalmente distingue al indio de las Sabanas; esta deformidad está figurada en la imagen con formas que no son naturales. Es que la imitación de la forma no es muy fácil con un cincel de simple aficionado o curioso (pues así se llama a esta clase de artista), porque para lograrlo se necesita estudios preliminares que

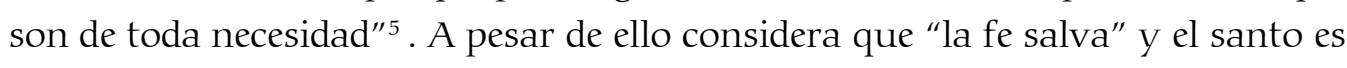
milagroso, aún con las "imperfecciones artísticas". El argumento central del francés para afirmar que el autor de la efigie es un nativo, se basa en que para él, y desde luego para los europeos en ese momento, lo único bello era lo griego. Así lo afirma cuando dice: "parece hecha por algún artista indígena, que de seguro no poseía el ideal de la belleza griega"6 . Para Striffler la aparición como la fama de ser muy milagroso es posterior a la conquista, no arriesga a informarnos

${ }^{3}$ SGARBOSSA, Mario y GIOVANNINI, Luis. Un Santo para cada día. 4ed. San Pablo, Bogotá, 1994. Pág. 260.

${ }^{4}$ FALS Borda, Orlando. Resistencia en el San Jorge. Historia Doble de la Costa No. 3, Carlos Valencia, Bogotá, 1984. Pág. $62 \mathrm{~A}$ y $63 \mathrm{~A}$.

${ }^{5}$ STRIFFLER, Luis. El Río San Jorge. Gobernación del Atlántico, Barranquilla, Sin fecha. Pág. 34.

${ }^{6}$ Ibid. Debe señalarse que todas estas leyendas y apreciaciones del francés, fueron presenciadas y consignadas en sus diarios desde la década de los cuarenta del siglo XIX. 
una fecha posible. Pero da testimonio del grado de religiosidad popular de los Caribes al asistir a la fiesta y la devoción por la imagen.

Pero a la fiesta del 14 de septiembre le nació o le impusieron competencia. La razón es que en septiembre llueve mucho, "en esa época de invierno muchos peregrinos se abstenían de venir, entonces desde la década de los sesenta se pensó en otra fecha, que fuera veraniega que por lo general aparece antes de Semana Santa. Entonces se hace esta, que es más concurrida. La 'Fiesta del Perdón'”7 . En

el calendario cristiano aparece

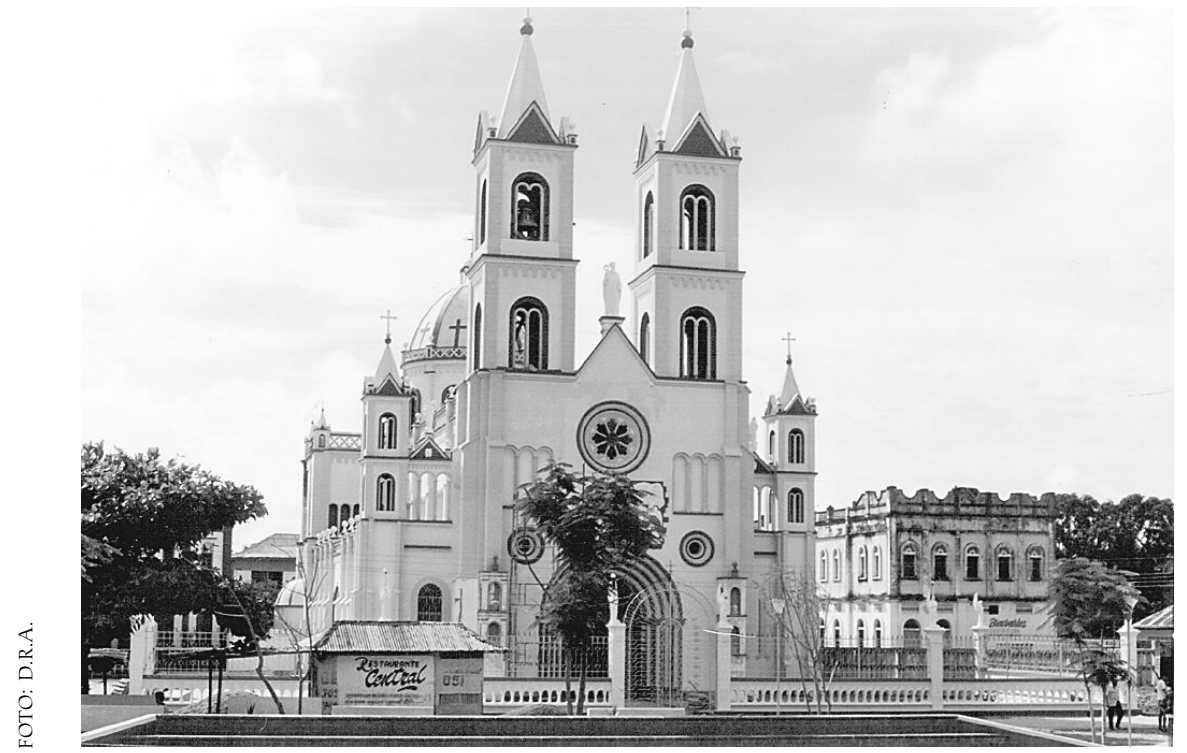
como una fiesta movible, que se celebra un domingo de Cuaresma. De tal manera que ya no es una peregrinación sino dos: una en verano y otra en invierno. La "Fiesta del Perdón" (la veraniega) está inspirada en el evangelio según San Lucas, en su capítulo 15, versículos 11 al 32 (parábola del Hijo Pródigo). Como toda fiesta cristiana, es precedida por un novenario, que sirve de preparación espiritual de los fieles creyentes. Cada día tiene su propia reflexión, además debe rezarse una oración para todos los días, al iniciarse el ritual y otra al finalizarlo. Cada novena es financiada por un devoto, que adquiere unos derechos y deberes especiales, entre otros arreglar lo mejor posible la iglesia. Quien financia una novena es siempre una persona pudiente del pueblo o de la región. En el 2003 costaba más de doscientos mil pesos ese derecho.

El anuncio de la llegada de los huéspedes-promeseros a San Benito no solo son los pitos sino también los chorros de luz de las lámparas de los buses que entran por las goteras del poblado por calles angostas y polvorientas. A esa hora de la madrugada, la promesera organizadora del bus en que hemos llegado venidos desde Santa Marta trata de guiar al conductor por los callejones del pueblo. Al llegar a la casa previamente contratada para alojarnos, hombres y mujeres con maletas y bolsos y con sus hamacas al hombro, buscan el mejor lugar para

7 PATERNINA Gutiérrez, Lácides. Entrevista en marzo 2003, San Benito Abad. guindarlas. Cuando han resuelto el problema de dónde dormir, se lanzan a la iglesia, en la plaza, buscando llegar rápido a la fila interminable de feligreses que se acercan al Cristo para sobarlo o tocarlo con un pedazo de algodón. 
El algodón a partir de ese momento se hace milagroso. El creyente considera que en cualquier momento lo necesitará porque tiene poder para aliviar dolencias y enfermedades, así me lo confirma Magdalena: "cuando yo tengo un dolorcito de cabeza o en otra parte del cuerpo, me sobo con el algodón y el dolorcito desaparece. Por eso lo cuido para que me alcance hasta cuando vuelva" ${ }^{8}$. Otros buscan afanosamente la fila del confesionario para pedir perdón por los pecados cometidos y estar preparados para recibir el cuerpo de Cristo en la misa principal a las 11 de la mañana del día domingo, presidida por el señor obispo de la Diócesis de Sincelejo y un grupo de sacerdotes que llegan para ayudar al párroco del Municipio.

Nosotros también nos fuimos para la iglesia a contemplar la efigie y a los promeseros. En esas estábamos, cuando una señora se acerca y confundiéndome con un sacerdote me solicita, confundida: "su bendición padre". Sorprendidos por la solicitud, dudamos inicialmente pero, al

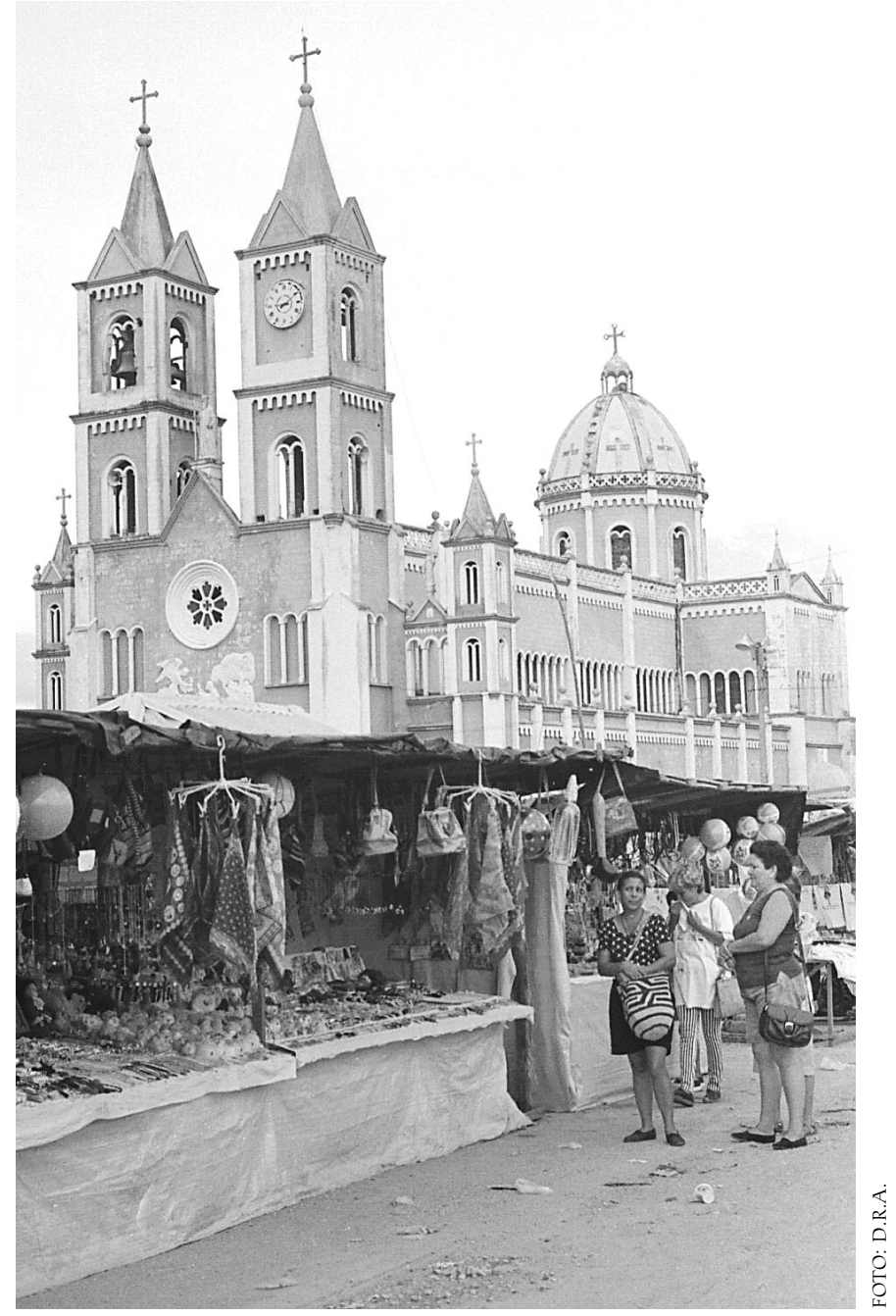
segundo, decidimos no aclarar nada y simplemente hacer la señal de la cruz y bendecir a la creyente. Pero no fue sólo a ella, sino a otras que iban con ella y otras personas más. Al fin pudimos superar la situación y nos metimos en la fila. La mayoría de los promeseros venía de Barranquilla. ¿Por qué tantos promeseros de esa ciudad? ¿Acaso es una ciudad de favorecidos por El Milagroso?, ¿O es la más pecadora y arrepentida? Supe que en su mayoría no son nacidos en Barranquilla, pero El Milagroso les ha ayudado a quedarse en la ciudad cuando salieron de su pueblo natal. Todos dan una explicación de su presencia en la Villa. Unos llegaron esperanzados en que la suerte les cambie, otros, esperando que el Cristo los proteja, otros más asisten para pagar una manda por un favor recibido. Todos llegan, vienen a cumplir lo prometido y expresar su agradecimiento al Cristo de la Villa. No importa qué tanto tuvieron que hacer para llegar, pero llegaron, y llevan distintivos que aluden a su origen, motivos y devoción.

${ }^{8}$ SARMIENTO Morales, Magdalena. Entrevista marzo de 2003, San Benito Abad. 


\section{La Feria del Milagroso}

El sábado la gente no cabe en el poblado. La fiesta cristiana cuenta con un aditamento: La Feria Comercial. La compra y venta de todos los productos que usted necesite. Camisas, zapatos, abarcas, ponchos, sandalias, carteras, pintalabios, pintauñas, adornos y hasta camisetas de equipos de fútbol. Fritos, dulces y comidas típicas del Caribe. Ron y música. En medio de ellos, los recordatorios que se deben comprar para que sacerdotes, el Obispo y el mismo Milagroso bendigan: escapularios, estampas, camándulas, incienso, camisetas con la imagen del Cristo, crucifijos, ramas de eucalipto que baten durante la procesión. Los gritos de los oferentes de productos, les hacen a las personas olvidar el verdadero sentido religioso del viaje. Pero otros penitentes más piadosos se ofenden con tanto mercachifle alrededor. No queda espacio para caminar. Pero para las autoridades que cobran el impuesto por vender en esos días, ese conflicto moral no existe. Las cantinas improvisadas pululan y, por supuesto, también pagan.

El francés Striffler, varias veces citado en este texto, tratando de explicar el surgimiento de la Feria Comercial que se organiza en San Benito por siglos, comenta lo siguiente: "es seguro que atrayendo el Cristo un numeroso gentío el día de su fiesta, no faltaron comerciantes que se valieron de la ocasión para ofrecer al público sus artículos, lo que queda probado por el gran incremento que tomó la feria desde su comienzo. Es verdad que las transacciones que se hacían al principio no eran nada comparadas con las de los últimos tiempos. En los primeros años después de la Independencia sólo se presentaban unos tenderos, de Cartagena, que iban a realizar los artículos ya envejecidos de sus casas; y es posible que al principio no fueran ni esos sino, los de las Sabanas y Magangué, los que iniciaran el movimiento" ${ }^{\prime 9}$. De lo anterior se pueden inferir varias cosas: primero, Striffler supone que las ferias fueron originadas por la devoción al Cristo Milagroso; segundo, que las ferias se iniciaron años después de la Independencia, es decir, después de 1819; tercero, pone en duda si los primeros en propiciarlas fueron los cartageneros que iban a vender cosas "usadas"; ¿inicio de los anticuarios?, o si por el contrario los iniciadores fueron los sabaneros y magangueleños. No importa quienes fueron los inventores de la Feria, lo cierto es que según el francés tuvieron importancia hasta 1854, dándole paso a las Ferias de Magangué.

Otros elementos extraídos de la lectura del europeo nos permiten conocer que

${ }^{9}$ STRIFFLER, Luis. Op. algunos comerciantes de Cartagena y Santa Marta iban hasta Jamaica a buscar las mercancías que ofrecerían, mientras que los negociantes del interior del país 
se surtían de mercancías en los puertos sobre el mar de los Caribes en Colombia. Se consideraba que las ventas serían buenas después de la procesión, puesto que antes de ella nadie compraba, había cierta Z. Del interior del país llegaban los artículos nacionales que eran consumidos por los sabaneros, pero a veces no todo se vendía y entonces "los del interior y los de la costa se cambiaban entre sí los artículos que no habían podido realizar por dinero efectivo, cambio que era una ventaja para todos"10. Nos informa el europeo que inicialmente en la feria sólo participaban nacionales y luego aparecieron extranjeros. Los primeros fueron unos israelitas de Curazao que traían mercancías de las Antillas.

Pero aunque ya no son las grandes ferias del siglo XIX, hoy los mercaderes también llegan y en medio de ellos y sus mercaderías los fieles penitentes caminan. El profesor Lácides Paternina Gutiérrez considera a muchos de ellos "falsos peregrinos", que no son más que "una montonera de desocupados de la vida que vienen en busca del 'rebusque milagroso' vendiendo mercancías oropelianas a una población que vibra de la alegría porque en estos días 'ellos también se rebuscan'"11. Es cierto, muchos sambenitinos también organizan su tenderete en la puerta de la casa, ofrecen empanadas, caramañolas, jugos, tintos y como queda dicho la gran mayoría de viviendas se convierte en hoteles de paso. En medio del tropel de gente y mercancías, el sacerdote en la noche del sábado convoca a todos a la Santa Misa y a varios oficios religiosos. Todos se arremolinan en la puerta del templo y pretenden entrar, algunos no lo logran, y quedan molestos en la plaza por haber llegado tarde, culpando a la mujer remolona o al marido que jugaba dominó a esa hora por la tardanza. De todas maneras el ritual continuará en la plaza cuando terminen los oficios religiosos. Entonces el castillo y los fuegos artificiales explotan iluminando la noche.

Al final aparece la efigie del Cristo Milagroso. Los ihurras! y alabanzas al Santo Cristo se entonan y en los corazones palpita la alegría. Los creyentes entran en cierto trance. Unos acordes musicales preparados para la ocasión por la banda de música se dejan oír. Los feligreses se arremolinan y no tienen como moverse o caminar. Hay que quedarse quietos en un solo sitio. Hasta que el día de la víspera termina. La gran mayoría se desparrama entonces por las calles y callejones en busca de su hospedaje. Algunos se extravían, otros se quedan libando, otros más le apuestan al azar, otros se quedan comiendo. Los mercaderes más insistentes, entre dormidos y despiertos, ofrecen a esa hora sus mercancías. Pero otros se van a descansar, pues la jornada dura y buena está por llegar, y hay que estar preparados para el trajín que los espera.

${ }^{10}$ Ibid.

${ }^{11}$ PATERNINA Gutiérrez, Lácides. Regresaron las Peregrinaciones al Santuario del "Negrito". En: Revista Variedades de Sucre, No. 2. Pág. 35 y

Poco después, temprano en la madrugada los penitentes ya están haciendo fila 36 , sin fecha. 
12 SABOGAL, María Yolanda. Entrevista abril de 2003. Cartagena. para bañarse en el único baño de la vivienda, preparándose para el ritual principal. Al salir a la calle se aprecian nuevas caras, los penitentes han aumentado. Las ventas de comidas improvisadas, las fondas conocidas, los restaurantes tradicionales no dan abasto. La gente se pelea el plato de comida, sobretodo con bocachico y bagre. La hicotea no se consigue, está prohibido cazarla. Los oficios religiosos del domingo se cuadruplican. La Iglesia es pequeña para la inmensa cantidad de feligreses, algunos de los cuales han estado llegando desde hace 30 años. La misa principal se ha iniciado ceremoniosamente presidida por el Obispo de la Diócesis acompañado de varios sacerdotes. En el oficio, todos se arrepienten, se estremecen con la homilía del sacerdote y sienten la presencia del Cristo. En la medida en que avanza la ceremonia, los feligreses entran en una especie de trance. El llanto se apodera de muchos, todos rezan y piden perdón.

Mi compañera María Yolanda me cuenta qué vio y qué sintió la primera vez que asistió a la misa: "La noche anterior fui a la misa, la gente da testimonios de los beneficios recibidos. Un señor comentó que lo habían condenado a 15 años por un delito que no había cometido, se aferró al Cristo y lo soltaron al año de estar detenido. Una señora contó que cuando le detectaron cáncer no le dieron esperanzas. Entonces le pidió al Milagroso con mucha fe y devoción que la salvara. Con los días, volvió al médico y para sorpresa de todos ya no tenía el cáncer que le habían detectado. Estando en la iglesia se siente como una paz interior, una gran tranquilidad, se contagia uno de la gente que reza y canta con mucha alegría y devoción. La gente baila al son de los cantos y palmotea. Es como si estuvieran en una fiesta. Cuando el padre comienza a pedirle al Milagroso por todas estas personas, por los familiares, amigos, por los hijos de uno, todo esto produce una nostalgia que dan ganas de llorar, al igual que cuando la gente está dando sus testimonios. A la misa van numerosas personas, cuando termina y se comienza a salir tiene uno que agarrarse porque son tumultos que empujan. Es demasiada gente de ambos sexos"12.

Todos fueron convocados por una misma razón: pagar por un favor recibido. No se trata de pagar por adelantado, como hacen los arhuacos, kogis, arzarios o kamkuamos en la Sierra Nevada de Santa Marta, cuando realizan sus pagamentos por los favores que recibirán de la Madre Naturaleza, sino que es el favor efectivamente recibido del "Abogado de los pobres" o por el "Médico de los pobres". El Cristo de la Villa es eso para los miles de fervientes católicos. Todos están esperanzados en la salvación, todos están complacidos por cumplir su palabra. Una de esas personas es la señora Emilia Teresa Orozco Montuffar, de Aracataca, Magdalena, residente en Barranquilla. Desde su tierra natal fue con 
una hermana durante años a Valledupar a pagar una manda a Eccehomo, porque cuando era niña estuvo muy enferma. Recuerda que fueron vestidas de blanco, tanto en la procesión como en la misa, y sin zapatos. Posteriormente, decidieron hacer romería a San Benito, desde hace unos diez años. La tradición la conoció en Barranquilla, aunque una vecina la invitaba para que fuera. Ella "no le paraba bolas, hasta el día de una desaparición del hijo mío, Jairo. El no aparecía hacía como tres meses y la vecina me dijo: 'Ay, señora Emilia, encárgueselo al Milagroso de la Villa; vaya para ver qué sabe de él'; entonces yo llegué y me puse enseguida en contacto con el Señor, le pedí a él y le dije que yo iba a la Villa, pero cuando regresara de allá que supiera algo de mi hijo. Total que, cuando yo vine de la Villa, ya mi hijo había llegado a Santa Marta, venía de Curazao y de Aruba. Me dijo así: 'Casi me tiran al mar unos marinos, por asuntos de droga'. Yo le dije: 'iAy! Mijo, sería por eso tanta desesperación que yo tenía, que hice tanto de ir a la Villa y pedir por ti"13. Desde entonces la señora Emilia asiste rigurosamente a la Villa, "y he llevado conmigo a casi toda la gente mía". Ahora la señora Emilia está enferma, y le ha pedido al Cristo que la mejore para seguir cumpliendo la manda. Ella siente que es un milagro lo que hizo el Cristo por su hijo y ahora espera por ella.

Cuenta también doña Emilia que a una amiga suya, que ahora vive en los Estados Unidos, la llevó a San Benito. La amiga pidió al Santo que le fuera bien y le prometió que a cambio le iba a mandar una compra por un millón de pesos para los más necesitados. "Preciso", dice la Señora Emilia, "ella no pudo venir, pero me llamó de los Estados Unidos y me dijo: 'yo no puedo ir, pero sí va una hermana mía, ella les va a llevar una compra que yo le ofrecí a todos los necesitados'. Ella me dice que desde que el Milagroso le hizo el milagro es otra persona, y que las hermanas van todos los años y llevan bastantes regalos." 14

Un hermano, una sobrina, una hija, en fin, son tantos los familiares de la Señora Emilia beneficiados por el Cristo, que casi toda se viene a la Villa año tras año para pagar la manda. Cuando alguien no puede asistir, envía a un hijo o a un hermano o a cualquier familiar para que acuda con la condición de cargar el Santo, quemar unas espermas y, de paso, traerle a casa una botella de agua bendita y algodones con el sudor de El Milagroso. No nos permite dudar cuando dice: "Una sobrina estuvo grave de muerte, allá en Riohacha, y ella me dijo que le había pedido al Milagroso, porque ella le parecía que lo había visto una noche, y fue cuando le pidió y le dijo que si él la salvaba de esa peritonitis iba y cargaba el Milagroso. Poco después, se sintió curada, y fue y cargó el Cristo. Lo de otro hermano mío fue milagroso, a él lo operaron, yo lo vi grave de muerte, le ofrecí llevarlo y pagarle el pasaje y todo, y él le caminara toda la procesión y lo hizo, 
fue tres años seguidos, él me dice que recibió la bendición" ${ }^{15}$.

El Cristo de San Benito, de acuerdo a sus seguidores, tiene dos profesiones reconocidas y alabadas por quienes solicitan su intervención: la de abogado y la de médico. Pareciera que quienes más buscan y reciben sus buenos oficios son los pobres. Sin embargo, ricos y acomodados caribeños en deuda con el Cristo Milagroso también le requieren, como es el caso de Miguel "Happy" Lora y Bernardo Mercado, ambos boxeadores. Los dueños de los almacenes La Patria "patrocinaban las fiestas, ellos son unos ricos de aquí de Barranquilla"16. "Todo lo que parece garantizar su salud, su estabilidad, está considerado como santo; todo lo que parece comprometerlas se tiene por sacrílego"17. Por eso no importa la posición social que se ocupe, cuando existe una creencia del efecto positivo que causa una imagen, se le venera y en sus manos se coloca la vida.

En el año de 2003, mientras cargaban los bultos de ropa y comida para la romería, aproveché para conversar con varias personas compañeras de viaje. Una de ellas fue Yina Martínez, una joven secretaria, que iba por primera vez y llevaba entre sus brazos a su hija de 13 meses de nacida. Me dijo: "Yo hice una ofrenda al Señor de los Milagros, estando embarazada de mi hija y la voy a presentar. Prometí ir después que saliera bien del parto, así fue, y se la voy a presentar. Mi temor era por ser primeriza. Mis familiares me indujeron a creer en el Señor de los Milagros y gracias a él salí bien"18. Yina iba preocupada por los comentarios que conocía: mucha gente, mucho calor, pero fue enfática cuando me dijo: "hay que vivirlo para ver". De regreso se sentía feliz por haber logrado sobrevivir al "solazo y calorzazo" y haberle presentado su hija al Cristo. Yina cuenta también que el 5 de octubre de 2002 había sufrido un accidente en un bus, estuvo hospitalizada varios días, la familia y ella misma le pidieron al Cristo de la Villa que la salvara del golpe fuertísimo que recibió en la cabeza, pidieron todos con mucha fe y como ella misma lo ratificó: "La fe, la fe mueve montaña". Yina para ir contó con el apoyo de toda la familia e inclusive de su esposo, quien estuvo siempre pendiente de su viaje.

${ }^{15}$ Ibid.

${ }^{16} \mathrm{Ibid}$.

${ }^{17}$ CALLOIS, Roger. El hombre y lo sagrado, México, Fondo de Cultura Económica, 1996. Pág. 147.

18 MARTINEZ, Yina. Entrevista marzo, 2003, Barranquilla.
También en la estación en Barranquilla conversé con otras feligresas que tienen cupo en el bus. Una es Rosario Machado, oriunda de Guacamayal, pueblo enclavado en la Zona Bananera del Departamento de Magadalena, que en este año de 2003 era la tercera vez que asistía. "La primera vez fui a acompañar a una de las hijas mías, que estaba enferma y le había ofrecido al Milagroso ir tres veces como lo manda el reglamento porque le había mejorado el dolor de cabeza; a mí me gustó el asunto y seguí yendo. Ahora, gracias al Milagroso, yo estoy bien. Cuando tengo un problema, una dificultad, invoco el nombre del Cristo 
Milagroso. Para mi no hay otro santo sino el Milagroso. A él le encomiendo todo y a él le dejo todos mis problemas; que él me ayude y siento que él me ayuda frente a cualquier problema que le encomiende." ${ }^{19}$. Es que, al "negrito se le mira como un demiurgo: tiene la clave de la vida y de la muerte, del gozo y del dolor, y a él se puede acudir siempre, en presencia o en ausencia, para que ayude en toda clase de crisis, problemas, enfermedades y peligros. Y así ocurre milagrosamente, misteriosamente, en gran número de oportunidades" ${ }^{20}$.

Dos feligresas, ambas barranquilleras y de 72 años, había logrado entrevistar antes de partir para San Benito. Una es Magdalena Sarmiento Morales y la otra Teresa Vanegas. Magdalena es peregrina desde hace más de 10 años, es la primera vez que viaja con este grupo organizado en el barrio "Las Palmas". El motivo por el cual ella debe ir todos los años, es porque sufría de nervios. "Y yo fui y el Cristo de la Villa me curó, me alivie bastante, y ahí me quedé. Yo voy dos veces, en septiembre y ahora en marzo. El Milagroso me quitó los nervios esos que yo mantenía, yo estaba muy mal”21. Por su parte, Teresa lleva más de 15 años asistiendo con regularidad, y también sufría de los nervios. La situación de la alteración nerviosa se la originó por la muerte del esposo. "Cuando él murió quedé con los nervios que corría para la calle, andaba muy nerviosa. Entonces un compadre, viéndome en esa situación, me llevó. Ese primer año entré de rodillas desde la puerta de la iglesia hasta el altar. Las rodillas se me cortaron toditas. Me puse mal con tanta gente, y, claro, como caminé de rodillas yo como que me desmayé y me cogieron y me llevaron allá y me echaron agua bendita. Ahora voy a la misa y camino la procesión descalza"22. Teresa me comenta que una vecina que antes iba y que ahora va a una iglesia cristiana, la critica. No sólo por ir, sino también por participar en un grupo de adultos, "Tercera Edad", que tienen una comparsa y desfila durante "La Batalla de Flores" en los carnavales, además baila y toma tragos. Sin embargo, ella es firme en su devoción y se le enfrenta.

\section{Autoridad y Fe}

Ese domingo, terminada la misa principal, continúan otras hasta la una o dos de la tarde, cuando arranca la procesión. Mientras, los promeseros, penitentes y nativos se preparan. Algunos están recordando aquel episodio cuando "un Alcalde quiso que la imagen no saliera por la puerta original, que es la central por donde siempre ha salido, sino por la de la derecha, por lo que el Cristo se puso tan pesado que 200 cargadores que le llevaban no podían con él. En ese momento, el Alcalde, le dio un latigazo a la imagen y le dijo: "sigue la ley" y el Cristo bajó de

\footnotetext{
${ }^{19}$ MACHADO, Rosario. Entrevista marzo de 2003, Barranquilla.

${ }^{20}$ Op. cit. FALS Borda, Orlando. Pág. 66A

${ }^{21}$ SARMIENTO Morales, Magdalena. Entrevista marzo de 2003, Barranquilla.

22 VANEGAS, Teresa. Entrevista marzo de 2003, Barranquilla.
} 
${ }^{23}$ PATERNINA Gutiérrez, Lácides. Entrevista marzo de 2003, San Benito Abad.

${ }^{24}$ Op. cit. STRIFFLER, Luis. Pág. 34.

25 Manuel Huertas Vergara nos informa que el Maestro Gustavo José Somoza, egresado de la Escuela de Música de La Coruña (España), compuso la marcha fúnebre El Milagroso, cuando se incendió la Villa en 1852. Además, que en 1862 , en compañía de Bartolomé Torrente González, contribuyó a la fundación de "La Banda 14 de Septiembre" de San Benito, de efímera vida, que luego fue revivida por Marcial Martínez, cuyo nombre tomó la actual Banda de la Villa.

${ }^{2}{ }^{6} \mathrm{P}$ A T E R N I N A Gutiérrez, Lácides. Entrevista marzo de 2003, San Benito Abad. peso y pudo salir... a los seis meses se le encogió la mano al Alcalde ${ }^{23}$. Luis Striffler registra la leyenda señalando que si el Alcalde no se presenta, el Cristo se crecerá y no pasará por la puerta, impidiendo salir la procesión a recorrer las calles de la Villa. El investigador afirma: "El señor Alcalde tiene siempre el cuidado de evitar este milagro, presentándose en tiempo con su bastón o vara de justicia, para probar que hasta Dios tiene que obedecer a la autoridad civil" ${ }^{24}$. De tal manera que nunca debe faltar la autoridad civil para evitar este hecho; lo cierto es que a pesar de los problemas de seguridad del Alcalde en el 2003, Enrique Orozco, el día de la procesión estaba presente con sus secretarios.

Sin olvidar el detalle de la leyenda, bajo la inclemente canícula de las dos de la tarde, los peregrinos y cargadores inician el recorrido tradicional. Los equipos de sonido y algunos picós se apagan cuando alguien grita: "ya salió el Cristo". La pólvora que explota por los aires también lo anuncia. Al salir por la puerta principal todos buscan su lugar. Al frente, desfilan los portaestandartes y portabanderas de congregaciones religiosas. Van también los portadores de pancartas. En una se lee: "Consagración al Señor de Los Milagros. Familia Cruz Pacheco". Otras personas portan una Cruz de madera, varias señoras llevan unos crucifijos. La procesión es acompañada por la banda de música "Marcial Martínez". Nunca descansa. Entre los temas se escucha "La marcha del Señor de Los Milagros"25.

Algo que todos los participantes saben es que la imagen que ahora llevan en hombros no es la figura original traída de España en el Siglo XVII, sino una réplica traída de Medellín, a la que, por tal razón llaman coloquialmente, el "Cristo Cachaco". La efigie original no la han vuelto a sacar a la calle desde hace unos 20 años, porque tiene "una fractura en el antebrazo izquierdo y desde ese momento se recomendó no sacarla. Imagínese, una imagen con tanto poder milagroso. Entonces se recomendó tallar una réplica y buscaron a un venezolano y a un italiano en Medellín, quienes tomaron las exactas medidas de la figura y la trajeron idéntica desde Medellín. De todas maneras, desde hace ya bastante tiempo, los mismos peregrinos dicen que también hace milagros" ${ }^{26}$, El acto de reemplazar imágenes originales por otras nuevas, tiene una historia de debates públicos en contra de la actitud de sacerdotes que las propician. Se conoce el caso de San Agatón, en Mamatoco, corregimiento de Santa Marta, donde los feligreses insistían en que el milagroso era San Agatón, pero el "viejo". En Magangué, Bolívar, el lienzo donde está la imagen de la Virgen de Nuestra Señora de La Candelaria se encuentra en un alto grado de deterioro por el tiempo. A 
pesar de ello, la feligresía magangueleña ha impedido que lo trasladen a Bogotá al laboratorio apropiado para su recuperación. La creencia popular considera que si se saca el lienzo puede producir una catástrofe en la ciudad.

Los feligreses-penitentes inician la procesión con el propósito de pagar debidamente por el beneficio recibido. La señora Emilia y su esposo José Antonio Rivadeneira me ratifican que cuando la imagen sale "dan ganas de llorar de la emoción, no se que será, pero uno llora. Debe ser de alegría, porque no es de tristeza. Uno llora porque siente cierta felicidad" 27 . Rosario, la otra entrevistada, me confesó que la primera vez que fue a La Villa, al ver El Milagroso en la calle y la cantidad de gente, "sentí mucha emoción, yo quería dar gritos de felicidad, las lágrimas se me salieron de la misma emoción"28. La fe que mueve a estos hombres y mujeres es la expresión de la creencia de que no fue la justicia ni la medicina humanas la que funcionó, sino la mano divina del Cristo Milagroso.

Y la manda hay que cumplirla como sea. Y ese es el sentido último de la celebración religiosa, que es, en últimas, el festejo místico del encuentro solidario entre samarios, cienagueros, monterianos, barranquilleros, malamberos, cartageneros, magangueleños, sincelejanos, guajiros, paisas, santandereanos y hasta venezolanos y ecuatorianos. Cada uno cumple como lo prometió: unos caminan de espaldas todo el recorrido de la procesión, otros de rodillas, otros más cargan la efigie del Cristo, aquéllos llevan manojos de espermas encendidas, que al derretirse queman sus manos, los de más allá van en silla de ruedas, tantos se disputan por cargar la efigie. Todos quieren tocar el Santo Cristo. Un padre se las ingenia, para que su hija enferma toque el Milagroso en busca de alivio a sus males. Cuando lo hace, cae en éxtasis, y contagia de entusiasmo religioso a su padre y a todos los que de lejos o de cerca presencian el acontecimiento. La temperatura sube, el bochorno es insoportable. Pero los sambenitinos y otros visitantes se han abastecido con tanques y baldes de agua que van arrojando a los peregrinos para hacerles más llevadero el cumplimiento de la manda. Los vendedores ambulantes aprovechan para ofrecer "el patillazo bien helado", "el tamarindazo frío", el agua fría en bolsa, el raspado de limón o refrescantes jugos de frutas tropicales.

Mientras los sacerdotes, religiosas y beatas intentan concentrarse en sus oraciones tradicionales, entonando cantos de alabanza, los devotos seglares se esfuerzan también por hacer sentir su presencia. Agitan consignas sacras, como iViva El Milagroso!, iViva el Abogado de los Pobres!, iViva el Médico de los Pobres!. O esta otra, en la que un solista agitador cristianísimo pregunta, “¿Quién es el que brilla?", a lo que responde la masa de promeseros: "El Negrito de la Villa", y

\footnotetext{
${ }^{27}$ RIVADENEIRA, José Antonio. Entrevista marzo de 2002, San Benito Abad.

${ }^{28}$ Op. cit. MACHADO Rosario.
} 
aplauden copiosamente. Todos en su momento entonan al unísono la consigna, adaptada para el momento, "Se vive, se siente, El Milagroso está presente". En medio del entusiasmo, nos hemos contagiado, y estamos aplaudiendo entre los demás y coreando las consignas. Me acerco a un promesero que camina de espaldas, que me dice sin haberle preguntado nada que se siente orgulloso de asistir una vez más al evento, luego de 19 años de estar haciéndolo luego que su hija fue salvada por el Cristo de una operación de la vena arteria, según reconocieron los mismos médicos que la atendieron. ${ }^{29}$. José Cogollo y su hija caminan igualmente de espaldas. Han llegado de Montería, con dificultades, casi sin dinero, a pagar la manda porque la niña estuvo muy enferma y El Milagroso "hizo su trabajo". Otra señora confiesa que ese día venía en el bus muy mal, se tomó una pastilla con agua bendita y se curó de inmediato. Una mujer, venida desde Cereté, Córdoba, portaba un manojo de espermas encendidas que le quemaban la mano. Afirma convencida que lo que hace está justificado: "Me parece que siempre es bueno que a una le duela siquiera un momentico".

El clímax llega a su punto más alto cuando la procesión se acerca al puerto de las lanchas, "chivos", yónsons, chalupas y canoas, que ponen a sonar sus sirenas, en expresión del sentimiento que les produce el paso del Santo Cristo. La imagen debe pasar por el puerto como lo estipula una tradición lugareña que dice que "el Cristo debe llegar a mirar la ciénaga, y en ese momento ninguna embarcación debe salir, y ningún navegante podrá dejar el puerto hasta que la imagen vuelva a entrar al santuario. Se cuenta que en cierta ocasión uno de los lancheros partió del muelle con un viaje de arroz y manteca y cuando la imagen del Santo Cristo recorría el lugar, la embarcación se hundió. Esta tradición también se aplica a los viajeros por tierra, por lo que ningún vehículo se atreve a movilizar mientras el Cristo no regrese a su Iglesia mayor."30 . Cumplido el requisito de llegar al barrio de El Puerto, y mirar las aguas de la ciénaga, la procesión se enruta por las calles y callejones del municipio que van siendo, a su paso, bendecidos, junto con los recordatorios y objetos que le son mostrados a su paso. Los enfermos que no pueden asistir esperan en las puertas de sus casas convencidos de que el sólo hecho de ver el paso de la procesión es suficiente para recibir las bendiciones que aliviarán o curará sus males.

${ }^{29}$ MARTINEZ, Narciso. Entrevista marzo de 2003, San Benito Abad.

${ }^{30} \mathrm{P}$ A T E R N I N A Gutiérrez, Lácides. Entrevista marzo de 2003, San Benito Abad.
Al regresar la efigie a la iglesia, la fiesta se da por terminada. Los visitantes recogen sus motetes y se inician las despedidas con besos, abrazos y promesas de retorno al año siguiente. Los buses que han estado estacionados cerca de la residencia de sus pasajeros se vuelven a llenar. Saben que el que salga antes de concluida la procesión se puede quedar varado en la vía 
Algunos destacan el sentimiento de tranquilidad que queda luego de participar en el evento religioso. Y haber cumplido la manda. "Me siento feliz. Y ahora que me devuelvo para Santa Marta soy otra"31. La señora Emilia reconoce sentirse "despejada; parece que me hayan quitado algo de mí, un peso. Me siento más tranquila. Distinta dice mi sobrina que se siente" ${ }^{32}$. "Siento la mente despejada de todo, me siento serenita", dice una de las que suben al bus con nosotros.

De vuelta a la ciudad de Santa Marta, nosotros también sentimos un alivio que termina con la redacción de estas notas. Aunque no necesariamente milagroso, una secuela importante de nuestro tránsito de peregrino, nos confirma en el hecho de que hay que saltar de las aulas de clase y del discurso académico e introducirse de lleno en la vida concreta de hombres y mujeres que con sus prácticas cotidianas, y en este caso particular, las religiosas, dan sentido a sus vidas. Y es ese sentido, vivo, actuado, sentido, sufrido y disfrutado, es al que hay que asomarse como ciudadano, vecino, hombre del común, para poder acceder a su significado y sentido. Definitivamente, como dice Durkheim, "el hombre depende de sus dioses, y la dependencia es recíproca. Los dioses también ellos, tienen necesidad del hombre; $\sin$ las ofrendas y los sacrificios morirían" ${ }^{33}$.

31 TORRES Hernández, Julia. Entrevista marzo de 2003, San Benito Abad.

${ }^{32}$ Op. cit. OROZCO Montuffar, Emilia.

${ }^{33}$ DURKHEIM, Emilio. Las formas elementales de la vida religiosa, Buenos Aires, Schapire S.R.L. 1968. Pág. 42.

\section{BIBLIOGRAFIA}

CAILLOIS, Roger. El hombre y lo sagrado, México, Fondo de Cultura Económica, 1996

DURKHEIM, Emilio. Las formas elementales de la vida religiosa, Buenos Aires, Schapire S.R.L. 1968

DUVIGNAUD, Jean. El Sacrificio Inútil. México, Fondo de Cultura Económica, 1979

FALS Borda, Orlando. Resistencia en el San Jorge. Historia Doble de la Costa No. 3, Carlos Valencia, Bogotá, 1984

HUERTAS Vergara, Manuel. Cabildo y merced de tierra, régimen para poblar el Partido de Tolú, Sabanas y Sinú, sin editorial, Sincelejo, 1992

PATERNINA Gutiérrez, Lácides. Regresaron las peregrinaciones al Santuario del "Negrito". En: Revista Variedades de Sucre, No. 2, sin fecha.

SAUDA Marrugo, Dora. Oración al Cristo Milagroso de la Villa de San Benito, Folleto, sin fecha.

SGARBOSSA, Mario y GIOVANNINI, Luis. Un Santo para cada día. 4ed. San Pablo, Bogotá, 1994

STRIFFLER, Luis. El Río San Jorge. Gobernación del Atlántico, Barranquilla, sin fecha. 


\section{ENTREVISTAS}

BARRIOS, Freddy. Entrevista marzo de 2003, San Benito Abad.

MACHADO, Rosario. Entrevista marzo de 2003, Barranquilla.

MARTINEZ, Yina. Entrevista marzo, 2003, Barranquilla.

MARTINEZ, Narciso. Entrevista marzo de 2003, San Benito Abad.

OROZCO Montuffar, Emilia Teresa. Entrevista marzo de 2002. Barranquilla.

PATERNINA Gutiérrez, Lácides. Entrevista marzo de 2003, San Benito Abad.

RIVADENEIRA, José Antonio. Entrevista marzo de 2002, San Benito Abad.

SABOGAL, María Yolanda. Entrevista abril de 2003. Cartagena.

SARMIENTO Morales, Magdalena. Entrevista marzo de 2003, San Benito Abad.

TORRES Hernández, Julia. Entrevista marzo de 2003, San Benito Abad.

VANEGAS, Teresa. Entrevista marzo de 2003, Barranquilla.

BIOGRAFÍA

EDGAR REY SINNING

Escritor, investigador de temas sobre la cultura popular del caribe colombiano, docente universitario y conferencista. Sociólogo (Universidad Cooperativa de Colombia- Sede Bogotá) y Magíster en Educación, Filosofía Latinoamericana (Universidad Santo Tomás). Docente. Se ha desempeñado como Secretario de Educación de Santa Marta y el Magdalena, Director del Instituto de Cultura del Magdalena y Asesor Cultural del CORPES, C.A. actualmente se desempeña como Director del canal regional Telecaribe. 